\title{
RANCANG BANGUN APLIKASI E-LEARNING UNTUK PEMBELAJARAN AGAMA ISLAM BERBASIS ANDROID (Studi Kasus MIN 6 Bandar Lampung)
}

\author{
${ }^{1}$ Putri Dwi Cantika, ${ }^{2}$ Bambang Hermanto \\ ${ }^{1}$ Jurusan Ilmu Komputer FMIPA Unila \\ ${ }^{2}$ Jurusan Ilmu Komputer FMIPA Unila \\ email : ${ }^{1}$ putridwicantika27@gmail.com, ${ }^{2}$ bbg.hermanto@gmail.com
}

\begin{abstract}
Islamic religious education is very important for human life, especially in achieving inner peace and mental health in general, Islam is the best life guidance, prevention of wrongdoing the most powerful, unmatched moral control. This system aims as an alternative media to facilitate children and teachers and parents who want to get information about Islamic learning materials for early childhood and elementary school children. In this research, E-Learning application for Islamic learning built based on android using Java programming language. The method used in this application is the Waterfall method, and is designed using Unified Modeling Language (UML). This application contains data of Islamic learning materials for children ages 3-11 years that can facilitate the user to understand and know the learning of Islam. The results of test data using Equivalence Partitioning testing, shows that the management rules (rule) system can run according to function and the system can provide information well. In addition, based on testing data, this application is the application of User Friendly variable category with an average value of 4.33 (very good).
\end{abstract}

Keywords: android, e-learning, islamic learning, java programming, unifield modeling language (uml).

\section{Pendahuluan}

Afrizal [1] Seiring dengan perkembangan Teknologi Informasi (TI) yang semakin pesat, kebutuhan akan suatu konsep dan mekanisme belajar mengajar (pendidikan) berbasis TI menjadi tidak terelakkan lagi. Konsep yang kemudian terkenal dengan sebutan e-learning ini membawa pengaruh terjadinya proses transformasi pendidikan konvensional ke dalam bentuk digital, baik secara isi (contents) dan sistemnya. Andry [2] Android adalah sebuah sistem operasi untuk perangkat mobile yang menyertakan middleware (virtual machine) dan sejumlah aplikasi utama. Android merupakan modifikasi dari kernel Linux.

Jalaluddin [5] Pendidikan agama Islam sangat penting bagi kehidupan manusia, terutama dalam mencapai ketentraman batin dan kesehatan mental pada umumnya. Tidak diragukan lagi, bahwa agama Islam merupakan bimbingan hidup yang paling baik, pencegah perbuatan salah dan mungkar yang paling ampuh, pengendali moral yang tiada taranya. Sebab agama bukan ibadah saja, agama mengatur seluruh segi kehidupan, semua penampilan ibu dan bapak dalam kehidupan sehari-hari disaksikan dan dialami oleh anak bernafaskan agama, disamping latihan dan pembiasan tentang agama, perlu dilaksanakan sejak si anak masih kecil, sesuai pertumbuhan dan perkembangan jiwanya. Anak mengenal Tuhan melalui ucapan ibunya waktu ia masih kecil. Apapun yang dikatakan ibunya tentang Tuhan akan diterimanya dan dibawanya sampai dewasa.

Dengan adanya aplikasi ini dapat memudahkan orang tua dan guru dalam memberikan pembelajaran agama Islam kepada anak-anak, dengan lebih menyenangkan melalui bacaan dengan animasi dan permainan edukatif yang disenangi anak-anak sehingga mereka lebih cepat menangkap pelajaran serta dapat digunakan dan dibawa kemanapun karena berbentuk software atau aplikasi dan diterapkan dalam perangkap Android sehingga lebih efisien dalam penggunaannya. 


\section{Metodologi}

Penelitian ini dilakukan berdasarkan diagram alir metodologi penelitian yang terdapat pada fugure1.Penelitian ini juga dilakukan berdasarkan metode pengembangan sistem yang dipilih yaitu metode Waterfall. Pressman [8] Metode waterfall adalah suatu proses pengembangan perangkat lunak berurutan, proses yang berjalan terus mengalir ke bawah (seperti air terjun) melewati fase-fase perencanaan, pemodelan, implementasi (konstruksi), dan pengujian. Tahapan pengembangan sistem dengan Metode Waterfall dijelaskan sebagai berikut:

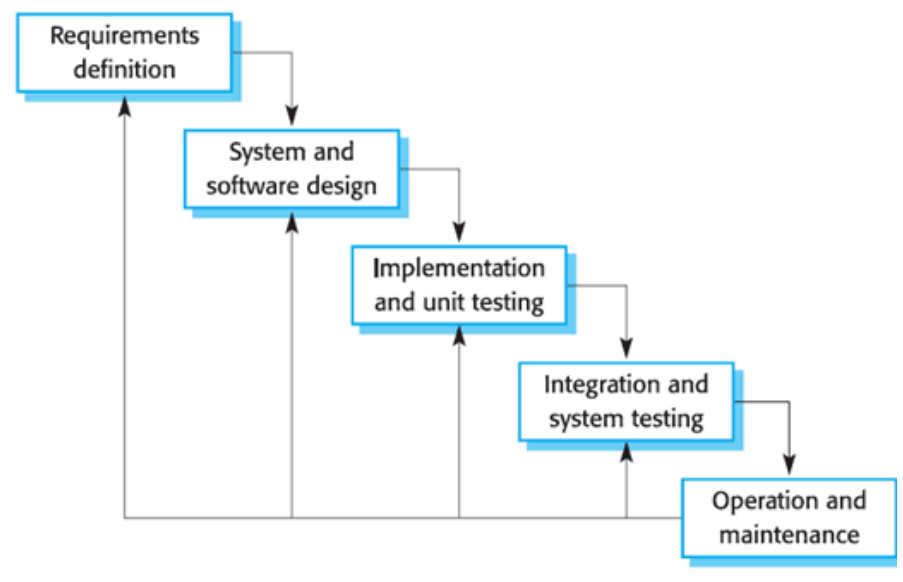

Gambar 1 Pressman [8] Metode waterfall

\section{Analisis Kebutuhan Aplikasi (Requirements Definition)}

Analisa kebutuhan sistem atau aplikasi merupakan tahapan pertama yang menjadi dasar proses pembuatan sistem. Pada tahap ini dilakukan pencarian dan pengumpulan semua kebutuhan yang diperlukan untuk menunjang kelengkapan sistem atau aplikasi, kemudian mendefinisikan semua kebutuhan yang dipenuhi dalam perangkat lunak atau aplikasi yang dibuat.

2. Desain Aplikasi (Sistem And Software Design)

Desain aplikasi merupakan tahap perancangan sistem atau aplikasi yang meliputi penyusunan proses, data, aliran proses, dan pemenuhan kebutuhan sesuai dengan hasil analisa kebutuhan. Dokumentasi desain aplikasi yang dihasilkan dari tahapan ini adalah use case diagram dan activity diagram.

3. Penerapan Desain dan Penulisan Kode Program

Penulisan kode program merupakan tahap penerjemahan desain sistem yang telah dibuat ke dalam bentuk perintah-perintah yang dimengerti komputer dengan menggunakan bahasa pemrograman. Penelitian ini menggunakan bahasa pemrograman java dan eclipse sebagai software pengembangan aplikasinya. Pada tahap ini, penulis menerjemahkan design kedalam bahasa pemrograman sehingga didapatkan suatu aplikasi yang diinginkan sesuai yang sudah dirancang. sehingga didapatkan suatu file installer dengan ekstensi apk.

4. Pengujian Aplikasi (Integration and Sistem Testing)

Pengujian aplikasi dilakukan untuk memastikan bahwa sistem yang dibuat telah sesuai dengan desain dan semua fungsi dapat dipergunakan dengan baik tanpa ada kesalahan sesuai dengan kebutuhan pengguna. Pengujian aplikasi ini menggunakan metode blackbox testing. Pengujian dilakukan secara menyeluruh tanpa melihat struktur internal aplikasi atau komponen yang diuji. blackbox testing berfokus pada kebutuhan fungsional aplikasi yang berdasarkan pada spesifikasi kebutuhan aplikasi tersebut.

5. Penerapan Aplikasi dan Perawatan (Operational and Maintenance) 
Pada tahapan ini, aplikasi sudah siap untuk diterapkan pada perangkat mobile dan siap digunakan sesuai dengan tujuan dibuatnya aplikasi ini. Perawatan, perbaikan dan pengembangan aplikasi dilakukan untuk menjaga kualitas dan kestabilan aplikasi.

\subsection{Alir Penelitian}

Penelitian dilakukan berdasarkan diagram alir metodologi penelitian yang terdapat pada Gambar 3.1. Penjelasan dari diagram alir metodologi penelitian pada Gambar 3.1 adalah sebagai berikut.

1. Pada langkah pertama, yang dilakukan pada tahap pertama adalah identifikasi masalah. Identifikasi masalah adalah pengenalan suatu masalah. Masalah penelitian akan menentukan kualitas dari penelitian, bahkan juga menentukan apakah sebuah kegiatan bisa disebut penelitian atau tidak.

2. Tahap kedua adalah perumusan masalah. Rumusan masalah adalah pertanyaan penelitian, yang umumnya disusun dalam bentuk kalimat tanya, pertanyaan-pertanyaan tersebut akan menjadi arah kemana sebenarnya penelitian akan dibawa, dan apa saja sebenarnya yang ingin dikaji.

3. Tahap ketiga adalah menentukan tujuan, manfaat dan batasan. Target pencapaian dalam tahap ini adalah diketahuinya tujuan dan manfaat dari Aplikasi e-learning Untuk Pembelajaran Agama Islam Berbasis Android. Sedangkan batasan digunakan untuk membatasi pembahasan dan ruang lingkup penelitian.

4. Tahap keempat adalah survei pendahuluan. Survei pendahuluan ini dimaksudkan untuk mengetahui hal-hal penting yang berhubungan dengan penelitian.

5. Tahap kelima adalah studi literatur. Studi literatur ini ditujukan untuk mendapatkan teoriteori dan hasil-hasil penelitian terlebih dahulu yang akan dijadikan landasan penelitian.

6. Memasuki langkah kedua yaitu tahap keenam. Langkah kedua adalah pengembangan sistem. Metode pengembangan sistem yang digunakan dalam penelitian ini adalah Waterfall. Tahap pertama yang dilakukan dalam pengembangan sistem ini adalah analisis kebutuhan aplikasi (Requirements Definition). Pada tahap ini akan dilakukan pencarian dan pengumpulan data berupa data dari pembelajaran agama Islam yang dikelompokan yaitu : rukun iman, rukun Islam, angka Arab, huruf Arab, malaikat dan tugasnya, tata cara wudhu, bulan-bulan Islam, tata cara sholat, nama-nama nabi, agama Islam. Pada tahap ini juga akan dilakukan analisis kebutuhan dasar sistem dan analisis user requirement.

7. Tahap ketujuh adalah desain aplikasi (Sistem and Software Design). Pada tahap ini akan dilakukan perancangan sistem dan perancangan antarmuka. Perancangan atau desain sistem dalam penelitian ini menggunakan Unified Modelling Language (UML), pada tahap ini akan diketahui semua entitas luar, input dan output yang terlibat dalam sistem serta use case, class diagram, activity diagram, sequence diagram yang digunakan dalam analisis sistem. Selanjutnya akan dilakukan perancangan antarmuka (interface), perancangan antarmuka ini dilakukan untuk merancang tata letak sistem sesuai dengan analisis kebutuhan sistem.

8. Tahap kedelapan adalah Penerapan Desain dan Kode Program (implementations and unit testing). Pada tahap ini akan dilakukan

9. Pembuatan program (koding) berdasarkan desain yang sudah dirancang sebelumnya.

10. Tahap kesepuluh adalah Pengujian Aplikasi (Integration and Sistem Testing). Setelah pembuatan program selesai, maka akan dilakukan pengujian. Pengujian aplikasi ini menggunakan metode blackbox testing.

11. Tahap kesebelas adalah Penerapan Aplikasi dan Perawatan (Operational and Maintenance) Pada tahap ini akan dilakukan penerapan sistem aplikasi ke-user (roll-out) melalui play store dan maintenance database aplikasi. 


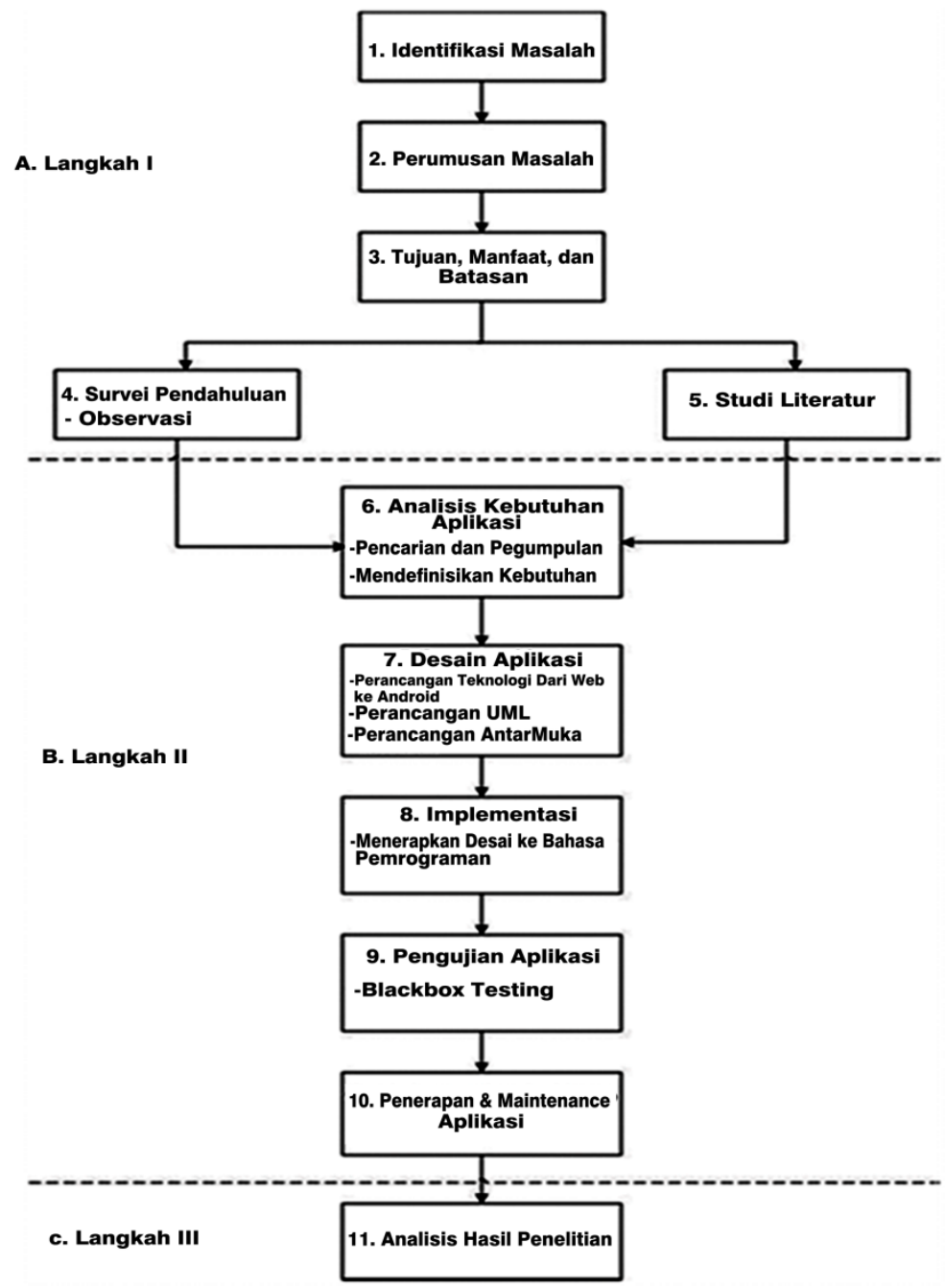

Gambar 1 Diagram Alir Metodologi Penelitian.

\section{Pembahasan}

Aplikasi e-learning pembelajaran agama Islam berbasis Android adalah aplikasi yang dibuat sebagai media pembelajaran agama Islam. Aplikasi ini dibuat dengan menggunakan bahasa pemrograman Java for Android dan PHP serta menggunakan MySQL sebagai manajemen database server aplikasi.

\subsection{Teknologi yang Digunakan}

Pembangunan aplikasi e-learning pembelajaran agama Islam berbasis Android ini dimulai dengan pengumpulan data-data materi pembelajaran agama Islam dari buku-buku SD. Selanjutnya merepresentasikan pengetahuan berdasarkan data-data yang didapatkan. Metode representasi pengetahuan yang digunakan yaitu kaidah produksi yang dituliskan dalam bentuk if-then. Representasi pengetahuan ini digunakan untuk menentukan proses pencarian. Pengolahan data pada aplikasi ini menggunakan Joomla dan dijadikan aplikasi Android menggunakan Android Studio. 


\subsection{Representasi Pengetahuan}

Representasi pengetahuan yang digunakan pada penelitian ini menggunakan kaidah produksi. Kaidah produksi dituliskan dalam bentuk jika-maka (if-then). Representasi pengetahuan ini digunakan untuk menentukan proses pencarian atau menentukan kesimpulan yang didapat.

\subsection{Implementasi Sistem}

Implementasi sistem dilakukan setelah tahapan analisis, perancangan sistem dan antar muka selesai dilakukan. Implementasi ini dilakukan untuk menyelesaikan sistem yang ada dalam dokumen rancangan sistem dan antar muka yang telah disetujui. Berikut adalah hasil implementasi system yaitu berupa tampilan aplikasi yang disajikan pada Gambar 2.

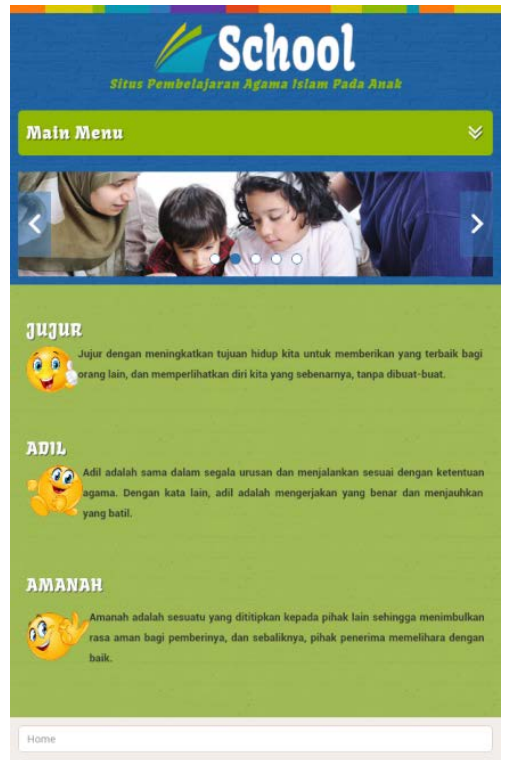

(a)

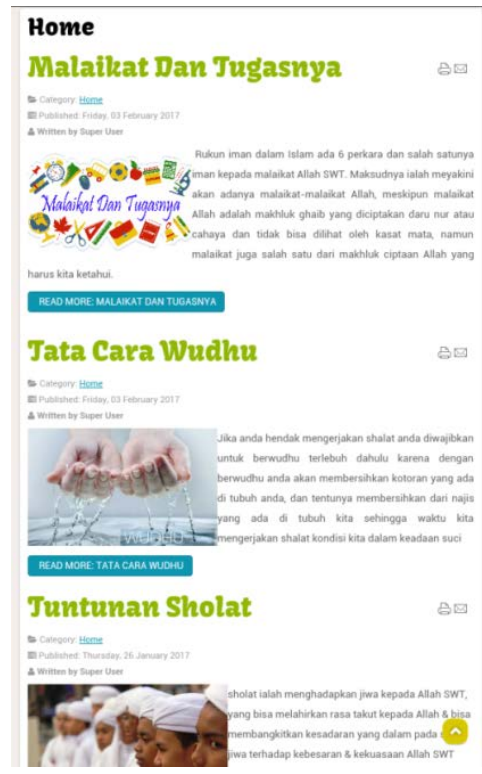

(b)

Gambar 2. Hasil Implementasi : (a) Halaman Utama, (b)Artikel Pada Menu Home

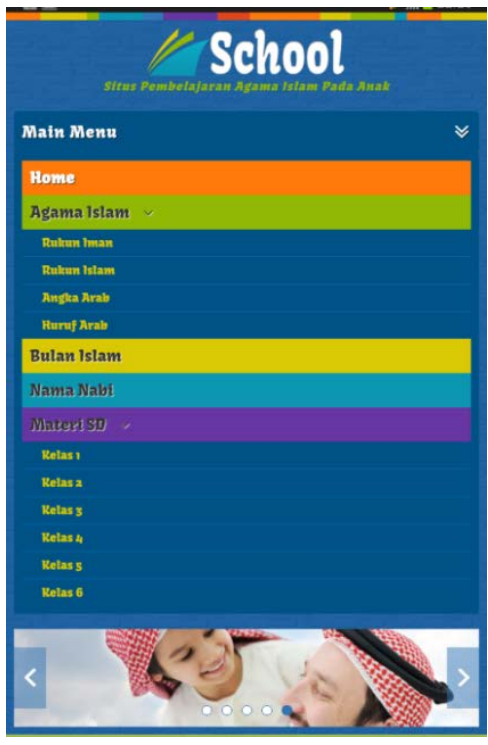

(c)

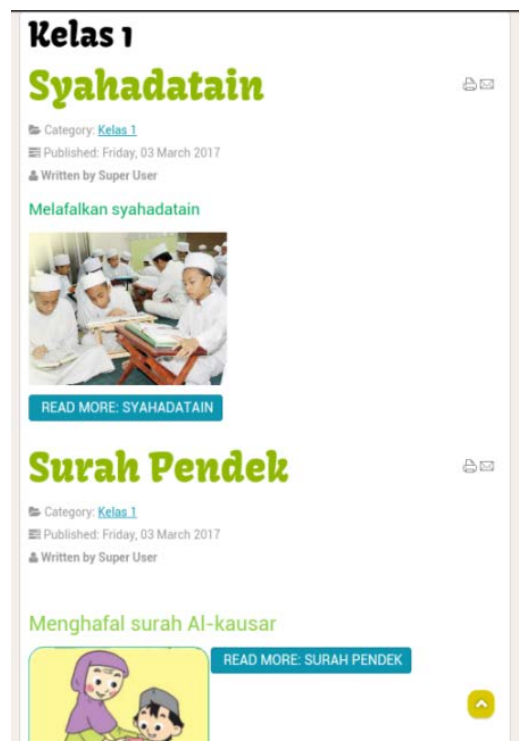

(d)

Gambar 2. Hasil Implementasi : (c)Macam-macam Menu, (d)Artikel Pada Menu Materi SD 


\subsection{Hasil Pengujian}

\subsubsection{Pengujian Fungsional}

Jiang [6] Pendekatan kasus uji fungsional dalam penelitian ini adalah pengujian black box dengan metode Equivalence Partitioning (EP). Pendekatan black-box merupakan pendekatan pengujian untuk mengetahui apakah semua fungsi perangkat lunak telah berjalan semestinya sesuai dengan kebutuhan fungsional yang telah didefinisikan. Pengujian ini dilakukan dengan membagi domain masukan dari program ke dalam kelas-kelas sehingga test case pada perangkat lunak dapat diperoleh. Terdapat 4 (empat) macam pengujian yang terdiri dari 8 (delapan) kelas uji dan 18 (delapan belas) skenario uji dalam pengujian ini. Dari pengujian tersebut diketahui aplikasi ini dapat berfungsi sesuai dengan realisasi yang diharapkan.

\subsubsection{Pengujian Nonfungsional}

Yitnosumarto [10] Sikap dapat diukur dengan metode rating yang dijumlahkan (method of summated ratings). Metode ini merupakan metode penskalaan pernyataan sikap yang menggunakan distribusi respons sebagai dasar penentuan nilai skalanya. Pengujian non fungsional melibatkan 50 (lima puluh) responden untuk mendapatkan penilaian langsung terhadap sistem yang dihasilkan. Pada pengujian ini responden menggunakan fungsi-fungsi pada aplikasi dan memberikan penilaian terhadap sistem.Dengan demikian pengujian non fungsional telah melibatkan 5 guru SD MIN 6 Bandar Lampung, 45 murid SD MIN 6 Bandar Lampung. Pengujian ini menggunakan lembar kuisioner yang berisikan pertanyaan-pertanyaan berkaitan dengan sistem yang dihasilkan. Penyusunan bentuk jawaban dari pertanyaan menggunakan skala likert. Sebelum dilakukan perhitungan dengan skala likert, dilakukan perhitungan interval terlebih dahulu. Perhitungan dilakukan dengan persamaan sebagai berikut:

$$
\begin{aligned}
& I=\frac{N T-N R}{K} \\
& I=\frac{5-1}{5}=0,8
\end{aligned}
$$

Setelah besarnya interval diketahui menggunakan rumus pada Persamaan 1, kemudian dibuat rentang skala sehingga diketahui dimana letak rata-rata penilaian responden terhadap setiap poin variabel.Rentang skala tersebut disajikan pada Tabel 1.

Tabel 1 Interval dan Kategori Penilaian

\begin{tabular}{cl}
\hline Interval & \multicolumn{1}{c}{ Kategori } \\
\hline $4,24-5,04$ & Sangat Baik (5) \\
$3,43-4,23$ & Baik (4) \\
$2,62-3,42$ & Cukup Baik (3) \\
$1,81-2,61$ & Kurang Baik (2) \\
$1,80-1,80$ & Tidak Baik (1) \\
\hline
\end{tabular}

\subsubsection{3.4.2.1 Variabel Fungsi aplikasi e-learning untuk pembelajaran agama Islam berbasis Android}

Hasil penilaian variabel aplikasi e-learning untuk pembelajaran agama Islam berbasis Android disajikan pada Tabel 2. 
Tabel 2 Hasil Penilaian Variabel Aplikasi e-learning untuk pembelajaran agama Islam berbasis Android

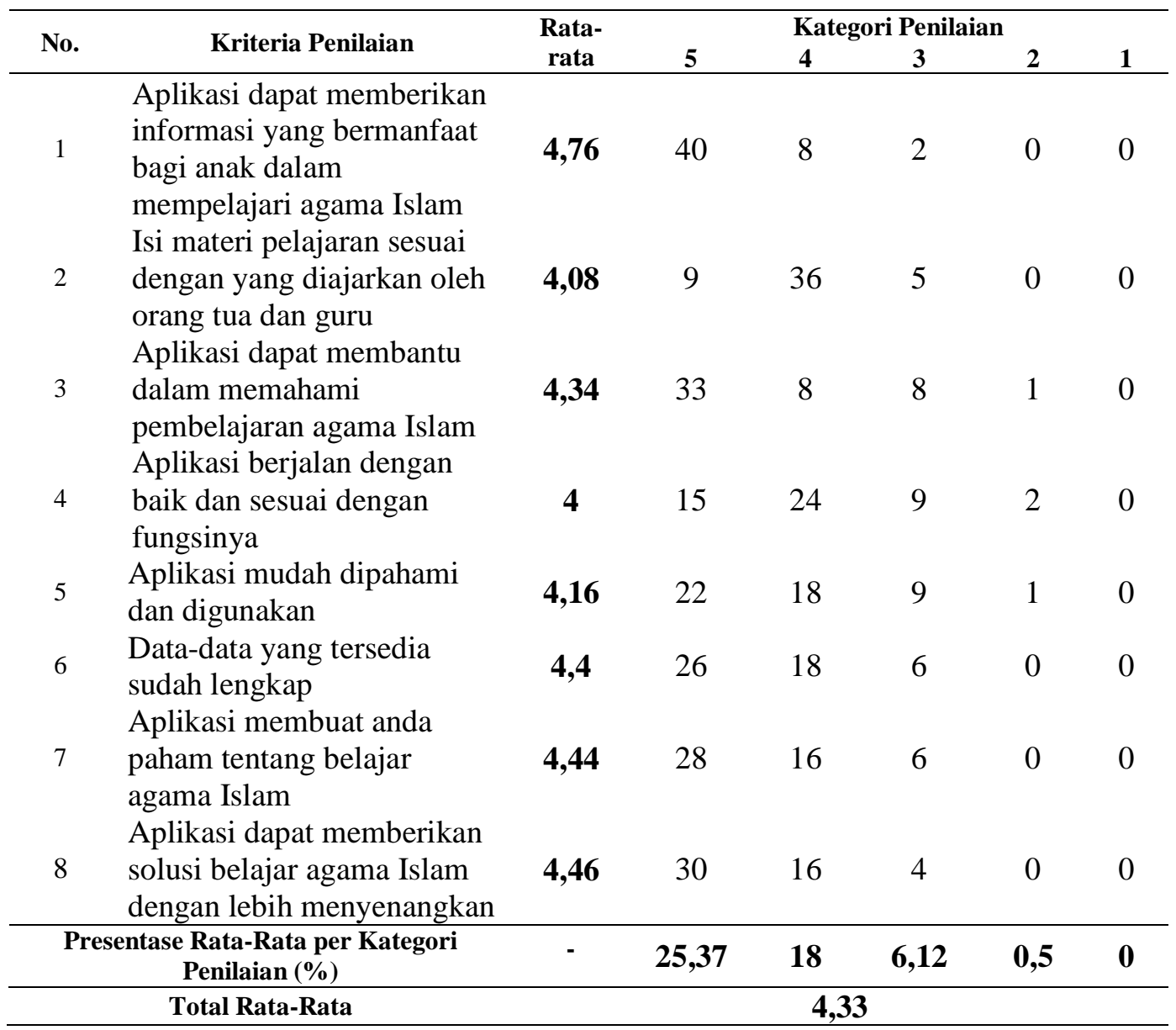

Total rata-rata yang diperoleh pada variabel aplikasi $e$-learning untuk pembelajaran agama Islam berbasis Android adalah 4,33. Berdasarkan interval dan kategori penilaian pada Tabel 2, maka variabel aplikasi e-learning untuk pembelajaran agama Islam berbasis Android masuk dalam kategori "Sangat Baik".

\section{Simpulan}

Berdasarkan hasil penelitian yang telah dilakukan dapat disimpulkan beberapa hal sebagai berikut:

1. Telah berhasil dibangun Aplikasi e-learning pembelajaran agama Islam berbasis Android yang dibuat sebagai sarana penunjang pendidikan dalam mempelajari agama Islam untuk anak usia 3-11 tahun.

2. Aplikasi telah berhasil menampilkan materi pembelajaran seperti tatacara wudhu, tata cara sholat, malaikat dan tugasnya, rukun Islam, rukun iman, angka Arab, huruf Arab, bulan Islam, nama-nama nabi dan materi SD. 
3. Dari hasil data pengujian Equivalence Partitioning, aplikasi e-learning untuk pembelajaran agama Islam berbasis Android kompatibel terhadap semua versi OS Android dengan minimum requirement yang telah ditetapkan dalam pembuatan aplikasi, kompatibel terhadap device Android dengan resolusi 4.0inch, 4.5 inch, 5.0 inch, 5.5 sampai 6 inch, namun ideal pada Android 5 inch dan dari semua kelas yang diuji aplikasi e-learning untuk pembelajaran agama Islam berbasis Android dapat berfungsi sesuai analisis.

4. Berdasarkan dari hasil data pengujian penilaian variabel user friendly dan variabel interaktif termasuk dalam kategori (Sangat Baik).

\section{Referensi}

[1] Afrizal, M. 2005. E-Learning Fisika Berbasis Macromedia Flash MX.Graha Ilmu: Yogyakarta.

[2] Andry. 2011. Android A sampai Z. Jakarta: PC plus.

[3] Jalaluddin. 2005. Psikologi Agama. PT Raja Grafindo Persada: Jakarta.

[4] Jiang F.Y.Lu. 2012. Software testing model selection research based on yin-yang testing theory. In: IEEE Proceeding of International Conference on Computer Science and Information Processing (CISP), pp. 590-594.

[5] Pressman R.S. 2001. Software Engineering A Practitioner's Approach Fifth Edition. McGraw-Hill Companies, Inc: New York.

[6] Yitnosumarto. 2006. Metode Penelitian Kuantitatif dan Kualitatif. Graha Ilmu: Yogyakarta. 